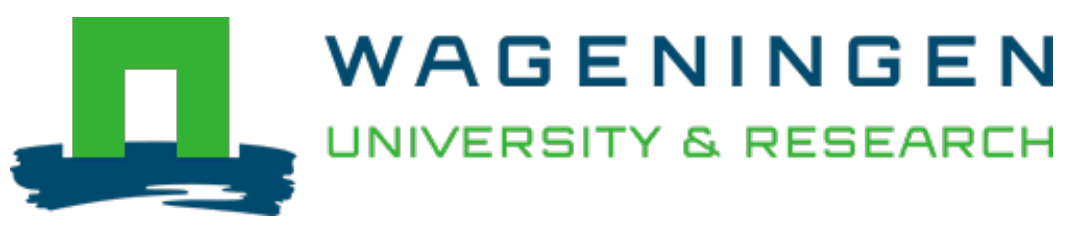

\title{
Chapter X.32: Large-scale water infrastructure, territorial transformation and water rights dispossession
}

\author{
Elgar Encyclopedia of Environmental Law \\ Boelens, Rutgerd \\ https://doi.org/10.4337/9781783477005.X.32
}

This publication is made publicly available in the institutional repository of Wageningen University and Research, under the terms of article $25 \mathrm{fa}$ of the Dutch Copyright Act, also known as the Amendment Taverne. This has been done with explicit consent by the author.

Article 25 fa states that the author of a short scientific work funded either wholly or partially by Dutch public funds is entitled to make that work publicly available for no consideration following a reasonable period of time after the work was first published, provided that clear reference is made to the source of the first publication of the work.

This publication is distributed under The Association of Universities in the Netherlands (VSNU) 'Article $25 \mathrm{fa}$ implementation' project. In this project research outputs of researchers employed by Dutch Universities that comply with the legal requirements of Article $25 \mathrm{fa}$ of the Dutch Copyright Act are distributed online and free of cost or other barriers in institutional repositories. Research outputs are distributed six months after their first online publication in the original published version and with proper attribution to the source of the original publication.

You are permitted to download and use the publication for personal purposes. All rights remain with the author(s) and / or copyright owner(s) of this work. Any use of the publication or parts of it other than authorised under article $25 \mathrm{fa}$ of the Dutch Copyright act is prohibited. Wageningen University \& Research and the author(s) of this publication shall not be held responsible or liable for any damages resulting from your (re)use of this publication.

For questions regarding the public availability of this publication please contact openscience.library@wur.nl 
Author accepted manuscript, cite as:

Boelens, R. (2021). Largescale water infrastructure, territorial transformation and water rights dispossession. In Elgar Encyclopedia of Environmental Law (pp. 425-437). Ed. Joseph Dellapenna \& Joyeeta Gupta. Edward Elgar Publishing Limited, Cheltenham and Camberley, UK and Northampton MA, USA. DOI: 10.4337/9781783477005.X.32

\title{
X.32 Large-scale water infrastructure, territorial transformation and water rights dispossession
}

\section{Rutgerd Boelens}

Professor of Water Governance and Social Justice, Wageningen University, Professor of the Political Ecology of Water, Centre for Latin American Research and Documentation, University of Amsterdam, and Visiting Professor, Catholic University of Peru and the Central University of Ecuador

\begin{abstract}
This chapter uses a political ecology approach to examine how large dams and megahydraulic infrastructure in many parts of the world dispossess smallholder families and communities of their water and water rights, transforming and disintegrating territories environmentally and socially. It deploys the notion of 'hydraulic property creation' to look at the relationships among hydraulic infrastructure development and changing water rights frameworks. It contrasts mega-hydraulic projects that separate designer-builder and user worlds, and user-developed hydraulic systems. It presents important points of attention for more people- and nature-inclusive water governance and hydraulic intervention projects that build on social and environmental justice.
\end{abstract}

\section{Keywords}

Large dams, mega-hydraulic infrastructure, water rights, water governance, environmental justice, hydraulic property creation

\section{Contents}

\section{X.32.1 Introduction}

X.32.2 Evaluating mega-hydraulics and water dispossession

X.32.3 Current justice issues related to large-scale water infrastructure

X.32.3.1 The rise of large infrastructure and its impacts

X.32.3.2 User-led water control systems and expert-developed megahydraulics: diverging rationalities and the impact on water rights

\section{X.32.4 Considerations for the future: more reflexive and equitable water policies}

\section{X.32.1 Introduction}

Throughout history, the burdens and benefits of large-scale water exploitation and development projects have been unevenly distributed, with different consequences for different social groups, places, and regions at various levels of scale. Control over wells and aqueducts in early societies led to water dispossession. With the increasing scale of hydraulic engineering the scale of dispossession increased. In many parts of the world, policies supporting urban-based modernity and industrial-commercial growth have produced specific forms of development that lead to rural marginalization. Large-scale water development projects make water available for growing urban water needs, hydroelectric generation, large commercial export agriculture, and industrial growth sectors, including large mining projects. These projects often claim water resources that are used 
for subsistence agriculture by local communities and available for ecosystems. ${ }^{1}$ Existing water uses and rights tend to be disregarded when water is allocated to be 'developed' for large-scale projects. This neglect, the expropriation of land and water it provokes, and the displacement of rural people that such projects often entail, trigger flows of migration to the expanding cities, further increasing urban water and energy demands. ${ }^{2}$

Using a political ecology focus, and the notion of hydraulic property creation, this chapter focuses on how large dams and mega-hydraulic infrastructure often dispossess smallholder families and communities of their water and water rights, thereby re-configuring territories institutionally, environmentally, and socially in ways that are difficult to reverse. It examines relationships among water's technological and normative/ sociolegal development (the interactions among hydraulic and water rights frameworks), contrasting user-developed hydraulic systems and mega-hydraulic projects. It also discusses how policies, knowledge frames, and politics mediate these processes, and what social responses they provoke. The last section focuses on the future and presents some points of attention for more reflexive water policies.

\section{X.32.2 Evaluating mega-hydraulics and water dispossession}

An important issue is how, in comparison with small user-built water works, large water development projects produce inclusion and exclusion, development and marginalization, and benefits and burdens, as well as particular water rights and property relations among different groups of people - and how such processes are contested and legitimized. ${ }^{3}$ Water, technology, and society are deeply interrelated in shaping 'hydrosocial territories'. ${ }^{4}$ In comparing large hydraulic infrastructure projects with (contemporary and previously existing) small dams, weirs, and diversion structures developed by farmers and user communities, it is crucial to see how different water acquisition, storage, and provision arrangements and distribution networks structure conditions of access and use for different categories of users.

How do different groups of people gain or lose access to water rights - in particular water flows (in terms of quality, quantity, timeliness, and security) and decision-making power over system governance - through hydrosocial transformations, choices of technology, and development of large versus small dam infrastructure. Such analyses need to include an examination of changing legal (including customary law-based) property in water and related resources (eg land), and how these are contested, legitimized, or agreed upon. ${ }^{5}$ This analysis builds particularly on the notion of 'hydraulic property creation' ${ }^{6}$ during water infrastructure development: how investing labour, financial, and other resources in building and maintaining water facilities establishes water property rights and water decision-making privileges among the water technology builders as

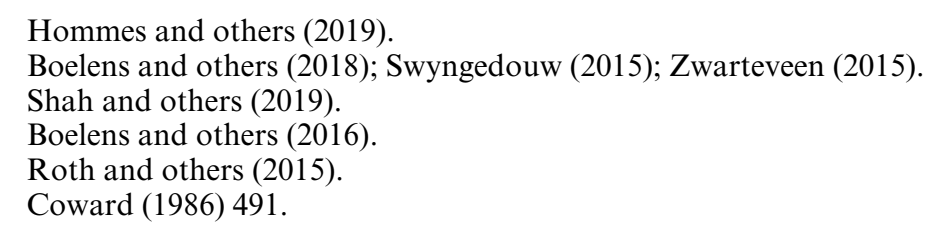


well as power relations with and within the broader political-geographic environment. ${ }^{7}$ Hydraulic property relations shape the normative-political basis for water system maintenance, operation, and governance action, and work differently for community versus governmental or private sector action.

\section{X.32.3 Current justice issues related to large-scale water infrastructure}

In recent decades, developing large-scale dams and river diversion schemes has been accompanied by large controversies. Mega-dams were beneficial for some social groups, but the social and environmental costs of water and energy production are huge for many, particularly marginal, population groups, as well as for local ecologies. In many places, people affected by hydropower projects and river diversion schemes, through dispossession, expropriation, or resettlement, have been left bearing the burdens but receiving no benefits. ${ }^{8}$ User-developed water control systems and water rights exhibit very different characteristics. This part explores how to understand the two approaches.

\section{X.32.3.1 The rise of large infrastructure and its impacts}

Swelling local and international controversies over large dams in the 1990s, as with the Sardar Sarovar Dam in India and the Three Gorges Dam in China, called for a review of the effectiveness of large dams but also proclaimed the need to rethink their impacts. ${ }^{9}$ Large-scale interventions in hydro-territorial systems have become icons of maldevelopment, representing capital-centric and construction-biased civil engineering projects based on supply-side hydrology that fail to recognize the complexity of river systems, ecosystems, and social systems. ${ }^{10}$

Despite two decades of widespread criticism of mega-dams on social and environmental grounds (leading to the withdrawal of international policy institutes and funding agencies), hydropower and large dam development have made a worldwide comeback, ${ }^{11}$ sometimes financed by local banks. ${ }^{12}$ In the global South, there are ambitious plans for new water resources development projects. Many of them are situated in the environmentally fragile upper catchments of large river systems, such as the Andes and the Himalayas, or in the world's crucial ecological or political regions, such as the Amazon and Nile basins. Unlike earlier large dam projects that were mainly spurred by agriculture and food security goals, these new developments are inspired by the need to meet rapidly growing water and electricity demands of industrial and non-agricultural sectors, including mega-cities and agribusiness.

Generating 'clean electricity' for a 'green economy' has become a main justification for dams and water storage schemes. ${ }^{13}$ The World Energy Council stated that in

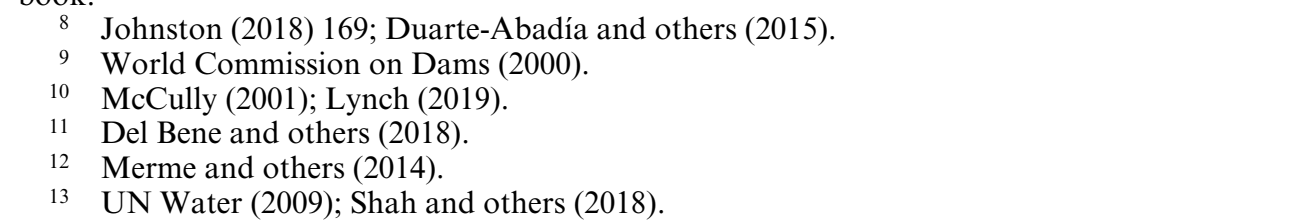


201576 per cent of all renewable electricity came from hydropower plants. ${ }^{14}$ The World Bank, criticized in the 1990s for its major support to ill-conceived mega-dam electricity projects, temporarily moved away from these projects, but since the early 2000s has returned to funding controversial big dam and water transfer projects. ${ }^{15}$ Dam development was reinvented and reframed in the strongly depoliticized language of overall progress, sustainable, clean development, and efficient, rational water management, disregarding 'competing claims and conflicts over water, landscape and hydropower development and assorted interrelated struggles over socio-cultural issues, problem definitions, knowledge frameworks, ontological meanings, decision-making and preferred solutions' ${ }^{16}$

At least superficially, new large water development projects display a greater awareness of their social and environmental consequences, and project plans often include meticulously detailed protocols for environmental impact assessments, mitigation, and compensation. In practice, however, much of this exists only on paper. The new water projects prioritize the needs of industries and big cities over those of food security, poverty alleviation, and rural livelihoods. Simultaneously, particularly in the global South but also in the North, ${ }^{17}$ grassroots organizations, displaced communities, and indigenous protestors are increasingly criminalized and violently suppressed for defending their land and water rights. ${ }^{18}$

Large dams are based on strong coalitions. Large-scale water infrastructure is often favoured over smaller and cheaper alternatives because of the powers and interests of the 'iron triangle' of bureaucrats, politicians, and engineers. ${ }^{19}$ These make effective use of 'normalizing' and legitimizing discourses of scarcity, efficiency, and national development to discredit alternatives that may be more socially and environmentally sound. What characterizes current social debates on dams is strong polarization mainly along a small-versus-large dichotomy. 'Bad' large infrastructure based on modern engineering is pitted against 'good' community-based, small-scale infrastructure. Yet 'small' and 'large' are relative categories and the scale of the infrastructure is not the only determinant of how water interventions impact on environment and societies. Small-scale infrastructure is also influenced by existing power structures and social differentiation based on class, caste, ethnicity, or gender. But scale and size certainly do matter. The sheer size of mega-dam development and operations makes them capital-intensive, requiring and building on universalist, positivist, expert-knowledge that cannot be found locally but is embedded in (trans-)national knowledge centres, engineering schools, and private sector consultancy networks. The above-mentioned 'iron triangle of powers' and impressive commercial gains give these projects enormous political interests, promote corrupt practices, and stimulate non-transparent operations. ${ }^{20}$ In addition to causing huge transformations of the existing hydrosocial environments, they build on the idea that economic growth must be pursued at all costs and ignore legal frameworks that recognize human

\footnotetext{
14 Menga and Swyngedouw (2018).

15 Lynch (2013).

16 Hommes and others (2016) 11.

17 Boelens and others (2019).

18 Eg Hidalgo-Bastidas and others (2018); Del Bene and others (2018); Lynch (2019).

19 Ajaya and Gyawali (2010); Molle and others (2009).

20 Dye (2016); Huber and Joshi (2015).
} 
rights and the rights of indigenous peoples, ${ }^{21}$ with local water rights remaining unnoticed, irrelevant, and undermined. Yet these localized, smaller hydraulic works - though not necessarily equitable to all - are characteristically based on local history, culture, site-available materials, organizational capacities, and knowledge frames.

\section{X.32.3.2 User-led water control systems and expert-developed mega-hydraulics:} diverging rationalities and the impacts on water right ${ }^{22}$

A fundamental issue is that, differently from user-developed water works, large infrastructure development separates the designer-builder and the user worlds, with profound consequences for property and water-governance power relationships. Locally developed and managed water control systems, such as irrigation, drinking water, or micro-watershed management systems, are complex institutions that dynamically interweave ecological, technological, normative, and economic domains with local histories, cultural patterns, and political structures - social configurations that constitute water user collectives' multi-domain balancing acts. Around the world, small communities and farmer groups manage irrigation systems developing their own diverse, often 'hybrid' water rights and control frameworks, now and in history. Water usually is diverted from rivers through small, rustic (often temporary) weirs that take part of the water and leave the rest for downstream communities, or it is taken from springs, creeks, and wells.

Water distribution modes in collective smallholder systems have commonly been consolidated through lengthy experiments and modifications. They are rooted in practices of generating and conserving water, investments made by families to gain these rights, and the rules governing inheritance and exchange of rights, all institutionalized in context-specific forms of customary law. In such user-developed systems, a water right legitimates claims to use particular quantities and qualities of water and decisionmaking privileges, under specified conditions and for specified purposes. The terms, obligations, penalties - the definition and contents of 'water rights' - differ from system to system, as do the mechanisms for acquiring and maintaining water rights. Humans' socio-environmental patterning is essential to capture water, operate water use systems, and materialize rights. ${ }^{23}$

Beyond legal constructs, water rights become manifest concurrently in hydraulic technology, normative arrangements, and organizational frameworks, all ingrained in particular political-economic and cultural-symbolic settings. Water user collectives in many parts of the world practice water rights under legal pluralism, whereby rules and norms of different origin and legitimization co-exist and interact in the same water territory. ${ }^{24}$ Most user-managed water use systems' rights frameworks dynamically interrelate rules, rights, and organizational forms from different sources, hybridizing local, national, and global rules. Water user collectives reinvent and experiment with their rights definitions and system operation codes. This continually shapes their collective water rights and their social and ecological boundaries, to defend against intruders, and to face outside

21 See Cosens, Chapter X.31 in this book.

22 This section is based on Boelens and Vos (2014).

23 Boelens and Vos (2014); Dellapenna and Gupta (2009); Shah and Boelens (2021).

24 von Benda-Beckmann and others (2006) 1. 
authorities and adverse environmental threats. Simultaneously, they organize each family's internal rights, in order to regulate day-to-day water practices and enable system operation and maintenance. Possible mechanisms for acquiring rights in user-managed irrigation (and often, drinking water) systems - arrangements that may operate concurrently or in various combinations are: State concession; historic rights; socio-territorial rights; transfer of water rights between right-holders; acquisition of water rights by force; and users' investment. ${ }^{25}$

Concentrating on users' investments illustrates how territories organize and are organized through particular patterns of water rights, hydraulics, and user organizations. In local water control systems, communities and families invest their resources (in-kind, labour, capital, time, and intellectual and ritual contributions) to build or rehabilitate hydraulic facilities, thereby creating their water rights. This was, and continues to be, institutionalized in numerous local and customary law frameworks all over the world, from Latin America, ${ }^{26}$ to North America, ${ }^{27}$ Europe,${ }^{28}$ Africa, ${ }^{29}$ Asia,${ }^{30}$ Australia, ${ }^{31}$ and in the Islamic water law tradition ${ }^{32}$ as well as in Hindu water law. ${ }^{33}$ Building water facilities establishes property rights, and the creation of irrigation works establishes property relations among the collective creators. These become the fundamental basis for their collective action in performing various water management tasks. ${ }^{34}$

'Hydraulic property creation' links individual water users to each other and to the collective system and entwines human-built property rights and material artefacts. It drives the formation of local water culture and identity, water rights defence, and collective social action in water control. The property creation mechanism guarantees that users, as collective bodies, will have effective control over the development and application of their own norms for system management. In many smallholder and indigenous systems, 'investments' can also be inherited (by families and communities as a whole). After creating property rights, users often consolidate them, again, through the logic of investment: by fulfilling operation and maintenance obligations to the water use system. Labour input, but also other investments in the upkeep of the hydraulic system, are important: financial contributions, agricultural produce, materials, instruments, intellectual inputs, and organizational efforts, and often 'cultural investments' such as joining in ritual activities. The consolidation of water rights through irrigation and drinking water systems' maintenance includes conserving the territorial (social and physical) infrastructure and the ecological environment. User groups often take water conservation measures in the catchment area that supplies river water for their irrigation systems: expanding their hydraulic property water rights to include a territorial claim to the river's headwater

\footnotetext{
25 Boelens (2015a).

26 Eg Paerregaard and others (2016).

27 Eg Wilson (2019).

28 Eg Boelens and Post Uiterweer (2013).

29 Eg Veldwisch and others (2019).

30 Eg Roth and others (2015).

31 Eg Jackson (2018).

32 Eg Naff (2009) 37.

33 Eg Cullet and Gupta (2009) 157.

34 Coward (1986).
} 
areas. ${ }^{35}$ Water rights creation and re-creation follows a general logic of user-managed water control. They build on a strong interdependence among three key domains:

1. generating and reconfirming rights (creating and recreating the normative framework);

2. constructing and rehabilitating infrastructure (creating and recreating the technological framework); and

3. creating and strengthening the organization (creating and recreating the organizational framework).

Users attempt, consciously or unconsciously, to synchronize and harmonize these aspects. The heart of a sustainable water use system is not so much the hydraulic infrastructure itself, or its management framework, but the interaction between the infrastructural, organizational, and normative sub-systems as expressed and materialized simultaneously in collective and individual property rights. ${ }^{36}$

Local customary rules drive many smallholders/indigenous water control systems around the world, yet go unnoticed by most water policy frameworks and water development interventions, and often are entirely absent from national water laws. Academics (legal, engineering, economics, anthropology, etc.) often lack the trans-disciplinary perspective to understand how water rights operate in conditions of legal pluralism combining official and unofficial legal systems while deeply moulded by material artifacts and technology. Adopting state- or market-centred norms and conceptualizations of water rights, they commonly structure policy in order to socially and legally engineer rational water use organizations and so-called efficient water management, by establishing 'modern' water rights and enforcing the rule of law. ${ }^{37}$

Colonial powers imposed their water law aiming to serve their interests instead of local communities. ${ }^{38}$ In post-colonial systems, with the domination of neo-liberalism, state- and market-centred water rights frameworks and water governance discourses have become fundamental cornerstones of mega-hydraulic system development and implementation. They build on engineering knowledge and pursue a growth agenda for the economy; in the process they implicitly create a different value system and water rules and energetically institute them, neglecting (and often, annihilating) local water control and rights. The basic rationality of well-functioning local water rights and governance institutions remains unknown, is misrepresented, or is undervalued by such a water policy focus. ${ }^{39}$

This more subtle, 'hidden,' or 'invisible' subordination of local water rights systems forms part of the overall, more visible ways in which mega-hydraulic projects and large dams cause profound transformation of hydrosocial territories. Large dam construction (including the development of large-scale irrigation systems replacing local ones) impounds water from the watersheds (rivers, springs, and aquifers) enabling corporate profits and often expropriates water resources that were previously used by subsistence

\footnotetext{
Boelens and Vos (2014).

Boelens (2015a).

Zwarteveen and Boelens (2014).

Bijker (2007); Gupta and Dellapenna (2009) 391.

Espeland (1998); Roth and others (2015).
} 
communities, indigenous peoples, local fishermen, and peasant families. This megahydraulic regime builds on a modernist normative and epistemological discourse, which is importantly founded on the 'Dark Legend of UnGovernance'. ${ }^{40}$ This untold legend involves a deep, often subconscious, neglect of the existence of diverse water cultures, values, and societies, and claims that local water territories are basically unruly and disorganized with unproductive ecologies, inefficient resource use, and continual water conflicts. It 'disfigures water societies by overlooking water users, meanings, values, identities, and rights systems on the ground. It then constructs its own water users, with identities that conveniently fit the models, with needs and rationales matching the imaginations of those in power, shored up in their science, technology, and policy towers ....'. ${ }^{41}$

The UnGov Legend presents mega-hydraulic projects as benevolent, shedding light in the darkness and bringing rational order to the water regime without the need to adapt to the realities and practices of local populations; it is these local populations and their territories that need to adapt, not the plans. ${ }^{42}$ Ignorance of the diversity of governance and knowledge forms involves erasing localities' place-making, place-experience and meaning-giving. ${ }^{43}$ This dominant normative and epistemological notion seeks to transform territories through the construction of mega-dams to fit the new extractive order, as an active 'un-imagination' of communities, knowledges, and livelihoods. ${ }^{44}$ Mega-hydraulic modernism (also 'high-modernism') ${ }^{45}$ converts inhabitants of 'hydrological zones' into 'uninhabitants ..., the convergent unruliness of "irrational" river people and an "irrational" river must be straightened out and channelled into a national culture of rational development. We thereby witness a combined assault on an "unregulated" river and purportedly "lawless" people ....'. ${ }^{46}$

With 'multiple modernities, ${ }^{37}$ the dam regime, its imaginaries, designs, and practices are not monolithic, yet there are commonalities within modernist large dam regimes. ${ }^{48}$ Neglect or dismissal of existing cultural and ecological diversity is a key element in constructing the modernist mega-hydraulic discourse.$^{49}$ The emphasis on humanity's ability to actively shape the physical and social water-world is another fundamental aspect. The realization of large dam projects is heralded as a step towards civilizing traditional societies in need of modernization, and nature as the Other, non-human, disordered, and savage that needs to be conquered and subjected to humanity's will and benefit..$^{50}$ Water's diverse cultural norms, meanings, values, language, and knowledge is reduced to a single rubric in order to arrive at one common metric: market-economic valuation and calculability, to make all social and material territorial elements measurable,

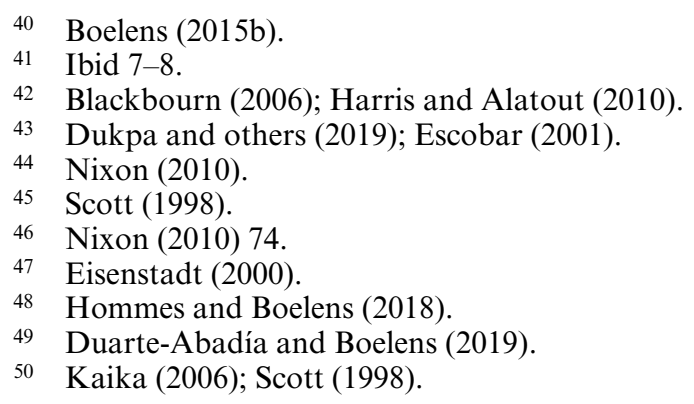


comparable, and transferable. ${ }^{51}$ The commodification of nature and society is fundamental for large-scale hydro-territorial development, and presented as a key process to materialize modern civilization.

... [P]erhaps more than any other development initiative, big dams have symbolized the progress of humanity from a life controlled by nature and tradition to one in which nature is ruled by technology, and tradition supplanted by science. On the other hand, big dams have more recently become symbols of the injustice of humanity through the untold destruction of nature, and the sacrifice of diverse cultures to inappropriate science and technology in the name of progress. $^{52}$

Large dam technology and 'iron triangle' power structures are intimately interrelated. It is not just a question of a ruling class, dam experts, or state agents seeking to politically, legally, and economically dominate peasant and indigenous hydrosocial territories, but of projecting their own particular way of seeing and ordering the water world as objective, natural, legitimate, and common-sense. Design efforts are geared towards mechanically and organically linking micro-water control society to meso- and macro-scales of technical-legal-political governance, generating new hydrosocial territories founded on mega-hydraulism. Contextualizing water rights, cultures, and peoples is irrelevant because the challenge is precisely to reduce all complex human and non-human phenomena to measurable, repeatable, foreseeable, calculable, and ultimately controllable terms, reshaping hydrosocial territories in line with frameworks of state administrations and (neo-liberal) market advocates. Creators of mega-hydraulic projects share the vision and mission that through hydro-productive and socio-legal engineering and standardization, they can manufacture 'rational' allocation patterns with 'functional' water rights, 'optimal' water schedules, 'efficient' water use, 'accountable' organizations, and 'disciplined' water users.

Designing, building, and implementing mega-hydraulic infrastructures brings particular modes of hydraulic property creation very different from user-driven property creation. Financial investors in large dams are not users and have different interests from users. Politically, planners and technical designers of mega works are not water users. Property creation follows diverse public-private partnership modalities. Infrastructure and water property rights are allocated to powerful state, private, or public-private coalitions. A few (elite) water users become 'clients' together with new (and often faraway) mining, agrobusiness, or hydropower water service buyers. A majority of local water collectives are erased and whenever local smallholder and indigenous groups gain access to water, they have top-down established water access rights without property and decision-making rights. Users' collective investment, democratic decision-making, and their control over system design, construction, operation, and maintenance is abolished. Given the capital-intensive design, construction, and implementation processes of mega-dams, building them demands powerful (trans-)national coalitions of funders, expert engineers, and national policy makers, all of whom intrinsically and automatically exclude local water collectives' involvement and any form

51 Hoogendam and Boelens (2019).

52 Khagram (2004) 4-5. 
of democratic and transparent institutions. Next to monopolies of expert-rule, the gigantic commercial gains and powerful political interests steer corrupt practices and non-democratic decision-making to the exclusion of smallholder collectives and their hydraulic property-rights creation.

Mega-hydraulic projects employ a modernist-rationalist discourse that portrays water administration as entirely plannable. Such neat social engineering is a myth. Water development realities are complex networks accommodating divergent values, norms, visions, interests, and expectations. Local groups may protest, boycott, or try to have their interests and ideas included.$^{53}$ While the official rules and policies are profoundly mediated by diverse actors and 'the stubbornness of reality', at the economic-politicaltechnical design table, mega-hydraulic dream schemes form a coherent, potent discursive system, rationally linking individuals and micro-water management systems to mesoand macro-scales of governance, creating self-fulfilling prophesies. If components of the model fail, it is not its inherent rationality or the modernization discourse that is questioned; blame is assigned to the social user groups who fail to apply it as 'rational clients' would. Besides powerful political and economic interests in mega-hydraulic development, there is a conviction that the myth must be realized.

\section{X.32.4 Considerations for the future: more reflexive and equitable water policies}

Mega-hydraulic infrastructure, such as large dams and river diversion schemes, heavily impact hydrological regimes, creating issues of social justice, human rights, and ecological concern. Dams uproot and often irreversibly alter livelihoods of local communities, while in most cases the projects do not deal adequately with the needs of project-affected people in the processes of design and dispossession through expropriation, resettlement, or rehabilitation. These problems arise from the powerful dam coalitions' social and material interventions in local livelihoods and managerial systems, but also from the epistemological and normative frameworks that are fundamental to mega-hydraulics' engineering and law- and policy-making.

Water bureaucracies and expert epistemic communities often continue to adhere to a perspective that primarily relies on the construction of large-scale infrastructure for water development, storage, and transport, following a market-based development model. This approach is based on and requires the concentration of rights and resources, the depletion of natural resources, and the dispossession of vulnerable groups. New water policies often propose to formalise and unify water rights in order to allow water to be transferable across uses and users. Existing forms of accessing and regulating water use often do not fit these new legal arrangements. The need to use and manage water more efficiently therefore entails normalizing and disciplining, often eroding existing livelihoods, ways of life, and cultural practices. Water governance must give greater attention to justice and equity. Interrogation of the choices inherent in these water governance policies is necessary, and of the power relations around proposed uses and controls of water, paying close attention to differences of class, caste, gender, and identity.

Water policy must pay more attention to the co-production of environment and society: The environment is as it is because of long historical trajectories of co-existence

53 Eg Duarte-Abadía and others (2019); Hidalgo-Bastidas and Boelens (2019). 
with humans. Through a transdisciplinary approach based on conceiving nature and society as co-constituted, policies can better grasp how environmental functions are shaped by interlinked environmental processes and human activities. This will fuel understanding of how socio-environmental processes work to re-define rights and obligations to water resources, to re-distribute benefits and burdens, and to legitimate these changes. A shift from existing mega-project-based knowledge traditions and hierarchic and prescriptive policy frameworks to more pluralistic, flexible, and interactive ones is necessary. This requires new ways of understanding socio-environmental realities and accepting more experiential and local forms of knowledge and rights frameworks, training water professionals in more pluralistic modes of dealing with water realities, and exploring more interactive water design and policy models.

Much thought and action on water problems continues to happen from a 'hydraulic mission' perspective, a mega-hydraulic planning mindset. Academic disciplines and policy agencies mutually constitute and reproduce each other, repeating the errors and dramas of large-scale hydraulic development and forming a major source of social and environmental injustice. The importance of critical reflection on the role of (academic and non-academic) professional water knowledges, and on rethinking established professional structures and routines, is increasingly recognized. Rather than imposing uniform policy ideas and water regulations, policy makers and implementers need to enter dialogues with grassroots communities and water user groups as deeply knowledgeable colleagues in water governance. Critical engagement does not deny but recognizes cultural and power differentials. Interactive policy and water design must be crafted to sustain user-oriented, equitable, and just territorial water governance.

This chapter results from research in the project RIVERHOOD which has received funding from the European Research Council (ERC) under the European Union's Horizon 2020 programme (grant agreement No. 101002921).

\section{Bibliography}

Ajaya D and Gyawali D, 'Nepal's Constructive Dialogue on Dams and Development' (2010) 3 Water Alternatives 106.

Bijker WE, 'Dams and Dikes: Thick with Politics' (2007) 98 Focus-Isis 109.

Blackbourn D, The Conquest of Nature: Water, Landscape and the Making of Modern Germany (Norton 2006). Boelens R, Water, Power and Identity: The Cultural Politics of Water in the Andes (Routledge 2015a).

Boelens R, Water Justice in Latin America: The Politics of Difference, Equality, and Indifference (University of Amsterdam 2015b).

Boelens R and Post Uiterweer NC, 'Hydraulic Heroes: The Ironies of Utopian Hydraulism and its Politics of Autonomy in the Guadalhorce Valley, Spain' (2013) 41 Journal of Historical Geography 44.

Boelens R and Vos J, 'Legal Pluralism, Hydraulic Property Creation, and Sustainability: The Materialized Nature of Water Rights in User-Managed Systems' (2014) 11 Current Opinion in Environmental Sustainability 55 .

Boelens R and others, 'Hydrosocial Territories: A Political Ecology Perspective' (2016) 41 Water International 1. Boelens R and others (eds), Water Justice (Cambridge University Press 2018).

Boelens R and others, 'Contested Knowledges: Large Dams and Mega-Hydraulic Development' (2019) 11 Water 416

Coward EW Jr, 'State and Locality in Asian Irrigation Development: The Property Factor' in Nobe KC and Sampath RK (eds), Irrigation Management in Developing Countries (Westview Press 1986).

Cullet P and Gupta J, 'India: Evolution of Water Law and Policy' in Dellapenna JW and Gupta J (eds), The Evolution of the Law and Politics of Water (Springer 2009).

Del Bene D, Scheidel A, and Temper L, 'More Dams, More Violence? A Global Analysis on Resistances and Repression around Conflictive Dams through C-Produced Knowledge' (2018) 13 Sustainability Science 637.

Dellapenna JW and Gupta J (eds), The Evolution of the Law and Politics of Water (Springer 2009). 
Duarte-Abadía BA and Boelens R, 'Colonizing Rural Waters: The Politics of Hydro-Territorial Transformation in the Guadalhorce Valley, Málaga, Spain’ (2019) 44 Water International 148.

Duarte-Abadía BA and others, 'Hydropower, Encroachment and the Re-Patterning of Hydrosocial Territory: The Case of Hidrosogamoso in Colombia' (2015) 74 Human Organisation 243.

Duarte-Abadía BA and others, 'Mobilizing Water Actors and Bodies of Knowledge: The Multi-Scalar Movement against the Río Grande Dam in Malaga, Spain' (2019) 11 Water 410.

Dukpa RD and others, 'Contesting Hydropower Dams in the Eastern Himalaya: The Cultural Politics of Identity, Territory and Self-Governance Institutions in Sikkim, India' (2019) 11 Water 412.

Dupuits E, 'Water Community Networks and the Appropriation of Neoliberal Practices: Social Technology, Depoliticization, and Resistance' (2019) 24 Ecology and Society 20.

Dye B, 'The Return of "High Modernism"? Exploring the Changing Development Paradigm through a Rwandan Case Study of Dam Construction' (2016) 10 Journal of East African Studies 303.

Eisenstadt SN, 'Multiple Modernities' (2000) 129 Daedalus 1.

Escobar A, 'Culture Sits in Places: Reflections on Globalism and Subaltern Strategies of Localization' (2001) 20 Political Geography 139.

Espeland WN, The Struggle for Water: Politics, Rationality, and Identity in the American Southwest (University of Chicago Press 1998).

Gupta J and Dellapenna JW, 'The Challenges for the Twenty-First Century: A Critical Approach' in Dellapenna JW and Gupta J (eds), The Evolution of the Law and Politics of Water (Springer 2009).

Harris LM and Alatout S, 'Negotiating Hydro-Scales, Forging States: Comparison of the Upper Tigris/ Euphrates and Jordan River Basins' (2010) 29 Political Geography 148.

Hidalgo-Bastidas JP and Boelens R, 'Hydraulic Order and the Politics of the Governed: The Baba Dam in Coastal Ecuador' (2019) 11 Water 409.

Hidalgo-Bastidas JPH and others, 'Hydroterritorial Configuration and Confrontation: The Daule-Peripa Multipurpose Hydraulic Scheme in Coastal Ecuador' (2018) 53 Latin American Research Review 517.

Hommes L and Boelens R, 'From Natural Flow to "Working River": Hydropower Development, Modernity and Socio-Territorial Transformations in Lima's Rímac Watershed' (2018) 62 Journal of Historical Geography 85.

Hommes L and others, 'Contested Hydro-Social Territories and Disputed Water Governance: Struggles and Competing Claims over the Ilisu Dam Development in Southeastern Turkey' (2016) 71 Geoforum 9.

Hommes L and others, 'Rural-Urban Water Struggles: Urbanizing Hydrosocial Territories and the Evolving Connections, Discourses, and Identities' (2019) 44 Water International 81.

Hoogendam P and Boelens R, 'Dams and Damages: Conflicting Epistemological Frameworks and Interests Concerning "Compensation" for the Misicuni Project's Socio-Environmental Impacts in Cochabamba, Bolivia' (2019) 11 Water 408.

Huber A and Joshi D, 'Hydropower, Anti-Politics, and the Opening of New Political Spaces in the Eastern Himalayas' (2015) 76 World Development 13.

Jackson S, 'Water and Indigenous Rights: Mechanisms and Pathways of Recognition, Representation, and Redistribution' (2018) 5 WIREs Water 1314.

Johnston BR, 'Large-Scale Dam Development and Counter Movements. Justice Struggles around Guatemala's Chixoy Dam' in Boelens R, Perreault T, and Vos J (eds), Water Justice (Cambridge University Press 2018) 169.

Kaika M, 'Dams as Symbols of Modernization: The Urbanization of Nature Between Geographical Imagination and Materiality' (2006) 96 Annals of the Association of American Geographers 276.

Khagram S, Dams and Development: Transnational Struggles for Water and Power (Cornell University Press 2004).

Lynch BD, 'Rivers of Contention: Scarcity Discourse and Water Competition in Highland Peru' (2013) 42 Georgia Journal of International and Comparative Law 69.

Lynch B, 'What Hirschman's Hiding Hand Hid in San Lorenzo and Chixoy' (2019) 11 Water 415.

McCully P, Silenced Rivers: The Ecology and Politics of Large Dams (Zed Books 2001).

Menga F and Swyngedouw E, Water, Technology and the Nation-State (Routledge 2018).

Merme V and others, 'Private Equity, Public Affair: Hydropower Financing in the Mekong Basin' (2014) 24 Global Environmental Change 20.

Molle F and others, 'Hydraulic Bureaucracies and the Hydraulic Mission: Flows of Water, Flows of Power' (2009) 2 Water Alternatives 328.

Naff T, 'Islamic Law and the Politics of Water' in Dellapenna JW and Gupta J (eds), The Evolution of the Law and Politics of Water (Springer 2009).

Nixon R, 'Unimagined Communities: Developmental Refugees, Megadams, and Monumental Modernity' (2010) 69 New Formations 62.

Nixon R, Slow Violence and the Environmentalism of the Poor (Harvard University Press 2011). 
Paerregaard K and others, 'Water Citizenship: Negotiating Water Rights and Contesting Water Culture in the Peruvian Andes' (2016) 51 Latin American Research Review 198.

Roth D and others, Liquid Relations: Legal Pluralism and Contested Water Rights (Rutgers University Press 2005).

Roth D and others, 'Property, Legal Pluralism, and Water Rights: The Critical Analysis of Water Governance and the Politics of Recognizing "Local” Rights' (2015) 47 Journal of Legal Pluralism and Unofficial Law 456.

Scott JC, Seeing Like a State: How Certain Schemes to Improve the Human Condition Have Failed (Yale University Press 1998).

Shah E and Boelens R, 'The Moralization of Hydraulics: Reflections on the Normative-Political Dimensions of Water Control Technology' (2021) 121 Geoforum 93.

Shah E and others, 'The UN World Water Development Report 2016, Water and Jobs: A Critical Review' (2018) 49 Development and Change 678.

Shah E, Vos J, Veldwisch GJ, Boelens R, and Duarte-Abadía BA, 'Environmental Justice Movements in Globalizing Networks: A Critical Discussion on Social Resistance against Large Dams' (2019) Journal of Peasant Studies, online doi:10.1080/03066150.2019.1669566.

Swyngedouw E, Liquid Power: Contested Hydro-Modernities in Twentieth-Century Spain (MIT 2015).

UN Water, The United Nations World Water Development Report 3: Water in a Changing World (Earthscan 2009).

Veldwisch GJ and others, 'Re-Introducing Politics in African Farmer-Led Irrigation Development' (2019) 12 Water Alternatives 1.

von Benda-Beckmann F and others, 'The Properties of Property' in von Benda-Beckmann F and others (eds), Changing Properties of Property (Berghahn Books 2006).

Wilson NJ, "Seeing Water Like a State?" Indigenous Water Governance through Yukon First Nation SelfGovernment Agreements' (2019) 104 Geoforum 101.

World Commission on Dams, Dams and Development: A New Framework for Decision-Making (Earthscan 2000).

Zwarteveen MM, Regulating Water, Ordering Society: Practices and Politics of Water Governance (University of Amsterdam 2015).

Zwarteveen MM and Boelens R, 'Defining, Researching and Struggling for Water Justice: Some Conceptual Building Blocks for Research and Action' (2014) 39 Water International 143. 